Article

\title{
Donor-Acceptor Substituted Benzo-, Naphtho- and Phenanthro-Fused Norbornadienes
}

\author{
Mads Mansø ${ }^{1,2}$, Lorette Fernandez ${ }^{2}$, Zhihang Wang ${ }^{2}$, Kasper Moth-Poulsen ${ }^{2}$ and \\ Mogens Brøndsted Nielsen 1,* \\ 1 Department of Chemistry, University of Copenhagen, Universitetsparken 5, DK-2100 Copenhagen Ø, \\ Denmark; madsmansoe@gmail.com \\ 2 Department of Chemistry and Chemical Engineering, Chalmers University of Technology, Kemivägen 10, \\ 41296 Gothenburg, Sweden; fernandez.lorette11@gmail.com (L.F.); zhihang@chalmers.se (Z.W.); \\ kasper.moth-poulsen@chalmers.se (K.M.-P.) \\ * Correspondence: mbn@chem.ku.dk; Tel.: +45-51700144
}

Received: 17 December 2019; Accepted: 9 January 2020; Published: 13 January 2020

check for updates

\begin{abstract}
The photochromic norbornadiene/quadricyclane (NBD/QC) couple has found interest as a molecular solar thermal energy (MOST) system for storage of solar energy. To increase the energy difference between the two isomers, we present here the synthesis of a selection of benzo-fused NBD derivatives that contain an aromatic unit, benzene, naphthalene or phenanthrene, fused to one of the NBD double bonds, while the carbon atoms of the other double bond are functionalized with donor and acceptor groups. The synthesis protocols involve functionalization of benzo-fused NBDs with bromo/chloro substituents followed by a subjection of these intermediates to a cyanation reaction (introducing a cyano acceptor group) followed by a Sonogashira coupling (introducing an arylethynyl donor group, $-\mathrm{C} \equiv \mathrm{CC}_{6} \mathrm{H}_{4} \mathrm{NMe}_{2}$ or $-\mathrm{C} \equiv \mathrm{CC}_{6} \mathrm{H}_{4} \mathrm{OMe}$ ). While the derivatives have good absorption properties in the visible region (redshifted relative to parent system) in the context of MOST applications, they lack the ability to undergo NBD-to-QC photoisomerization, even in the presence of a photosensitizer. It seems that loss of aromaticity of the fused aromatics is too significant to allow photoisomerization to occur. The concept of destroying aromaticity of a neighboring moiety as a way to enhance the energy density of the NBD/QC couple thus needs further structural modifications, in the quest for optimum MOST systems.
\end{abstract}

Keywords: aromaticity; chromophore; cycloaddition; norbornadiene; photoswitch; polycyclic aromatic hydrocarbon; ring strain; solar energy storage; Sonogashira coupling; quadricyclane

\section{Introduction}

Functionalized norbornadiene/quadricyclane (NBD/QC) couples have been identified as promising candidates for molecular solar thermal energy storage (MOST) systems that can undergo a closed energy cycle of light absorption, energy storage and energy release [1-3]. NBD undergoes a [2 + 2] cycloaddition upon irradiation, forming a strained high-energy QC isomer (Scheme 1). By introduction of donor-acceptor substituents on one or both double bonds of NBD, its absorption maximum can conveniently be redshifted from the UV to the visible region [4-6], thereby better matching the solar spectrum. This functionalization, however, decreases the energy density (from the optimum $1 \mathrm{MJ} \mathrm{kg}^{-1}$ of the parent system) on account of the increased molecular weight of the molecule. Yet, by using the same aryl group as a bridging substituent between two NBD units, this decrease in energy density can to some extent be counter-balanced [7]. 

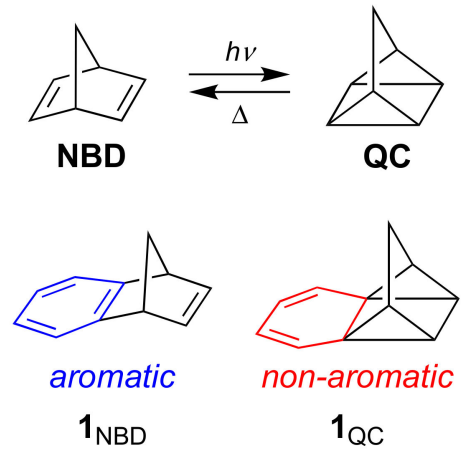

Scheme 1. Norbornadiene/quadricyclane (NBD/QC) interconversions and benzo-fused derivatives.

We became interested to investigate the possibility for other structural approaches of increasing the energy density. One approach could be to couple the isomerization reaction with loss of aromaticity of a fused benzene ring as shown for the benzo-fused couple $\mathbf{1}_{\mathrm{NBD}} / \mathbf{1}_{\mathrm{QC}}$ in Scheme 1. Yet, irradiation of derivatives of $\mathbf{1}_{\mathrm{NBD}}$ with various substituents at the benzene ring did not result in QC formation but instead in rearrangement reactions [8-10]. Along this line, some of us recently investigated benzo-fused dihydroazulene/vinylheptafulvene (DHA/VHF) derivatives [11,12]. For this photo-thermoswitch couple, benzannulation was also, in most cases, accompanied by the loss of the desired photoactivity of the DHA photochrome. A theoretical study showed that loss of aromaticity in the excited state reaction profile inhibits the DHA-to-VHF photoswitching [13]. In consequence, it seems that we need to seek a compromise by designing systems with less significant loss of aromatic character during photoswitching. One solution could potentially be to fuse a polycyclic aromatic hydrocarbon to the photochrome instead of just a single benzene ring.

Here we explore further the influence of benzannulation by fusing a benzene, naphthalene and phenanthrene unit to the one double bond of NBD, while at the same time maintaining an absorption in the visible region by donor-acceptor substitution at the other double bond, providing target molecules of general structures shown in Figure 1. As acceptor unit, we chose a cyano group, while $N, N$-dimethylanilino and anisyl groups connected via different bridges were chosen as donor groups. We present synthetic protocols for achieving such new derivatives and their properties.

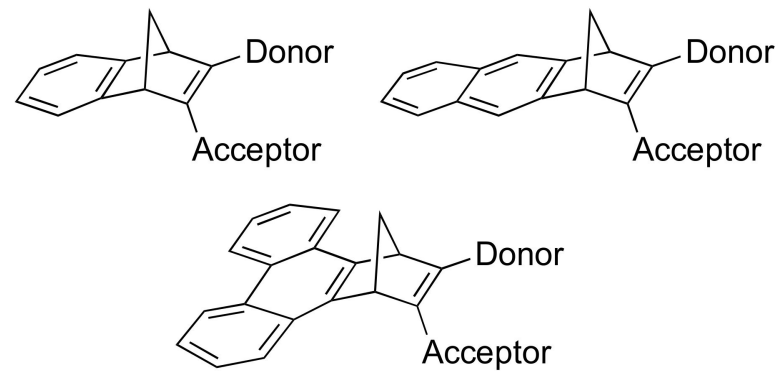

Figure 1. Norbornadiene target molecules with fused aromatic units at one double bond and donor-acceptor substituent groups at the other double bond.

\section{Results}

\subsection{Synthesis}

A one-pot procedure for introducing a bromo and chloro substituent at the one double bond of NBD has previously been described [14] and the resulting 2-bromo-3-chloronorbornadiene was used as a convenient precursor for incorporating donor and acceptor functionalities [6]. Subjecting in a similar manner the known [15] starting material 1 to the conditions shown in Scheme 2, we obtained the new chloro/bromo-substituted building block 2 . A cyanation reaction of this compound using $\mathrm{CuCN}$ in 
DMF (in analogy to conditions used for cyanation of the parent 2-bromo-3-chloronorbornadiene [6]) subsequently gave the product 3 where one cyano acceptor group has been introduced (Scheme 2). A small amount of the product 4 resulting from twofold cyanation was also isolated in this reaction.
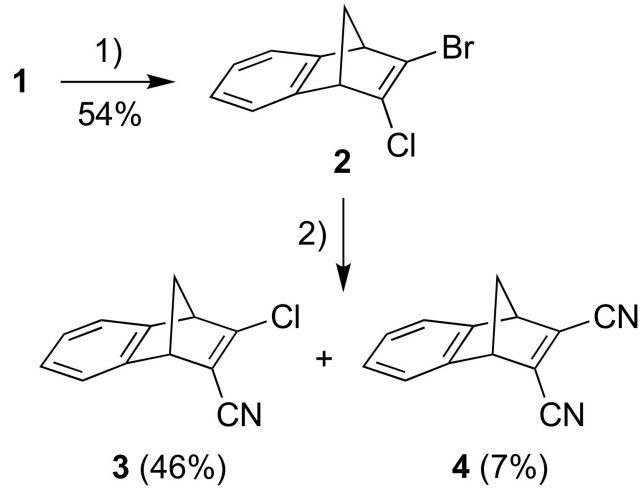

Scheme 2. Reagents and conditions: (1) i. $t$-BuOK, THF; ii. BuLi, $-84{ }^{\circ} \mathrm{C}$ to $-41^{\circ} \mathrm{C}$; iii. $\mathrm{TsCl},-84{ }^{\circ} \mathrm{C}$; iv. BuLi, $-84{ }^{\circ} \mathrm{C}$ to $-41{ }^{\circ} \mathrm{C}$; v. TsBr, $-84{ }^{\circ} \mathrm{C}$ to rt; (2) $\mathrm{CuCN}, \mathrm{DMF}, 105{ }^{\circ} \mathrm{C}$.

Next, we introduced anilino and anisyl donor groups by Sonogashira coupling reactions between 3 and the terminal alkynes 5 and $\mathbf{6}$, furnishing the products $\mathbf{7}$ and $\mathbf{8}$, respectively (Scheme 3). By employing more than two equivalents of the terminal alkynes, we obtained instead the products 9 and 10. The two products 9 and $\mathbf{1 0}$ bear a resemblance to previously reported compounds obtained from Sonogashira coupling with 3-iodoflavones and 3-iodothioflavones, and it is believed that this is due to a second palladium catalyzed coupling step [16].

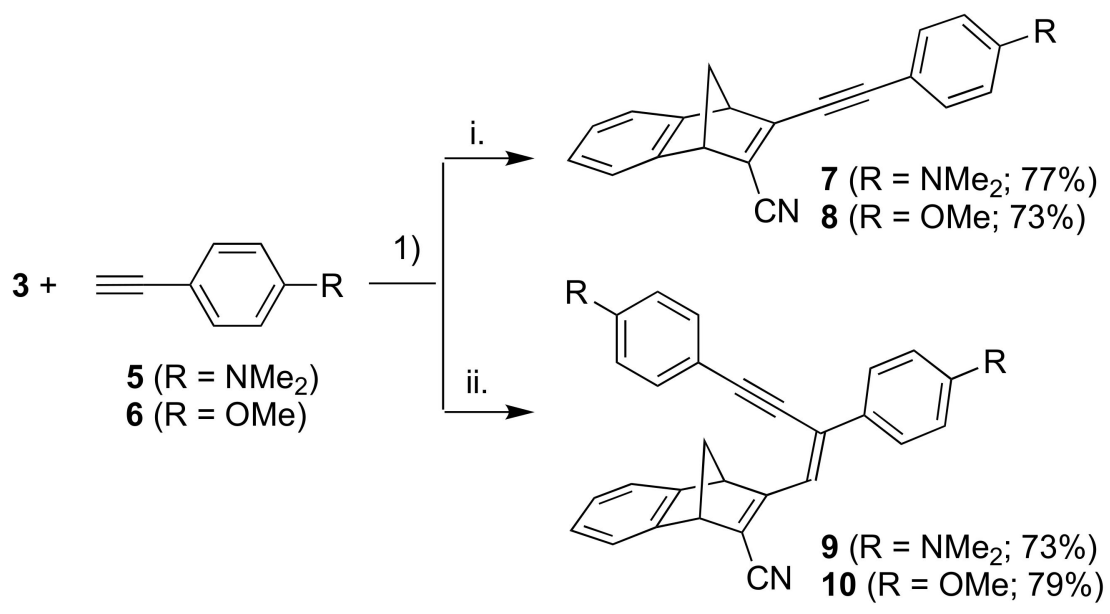

Scheme 3. Reagents and conditions: (1) $\mathrm{Pd}\left(\mathrm{PPh}_{3}\right)_{2} \mathrm{Cl}_{2}, \mathrm{CuI}, \mathrm{THF} / \mathrm{Et}_{3} \mathrm{~N}$; i. alkyne: 1 equiv.; ii. alkyne: excess.

Our next objective was to expand the aromatic unit to a naphthalene moiety. First, compound 11, prepared according to literature procedure [17], was subjected to a similar reaction sequence as above, providing the bromo/chloro derivative 12 (Scheme 4) (as an inseparable mixture with starting material 11). A subsequent cyanation reaction gave the product 13. Sonogashira couplings between 13 and alkynes 5 and 6 gave the donor-acceptor substituted products 14 and 15, respectively (Scheme 5). 


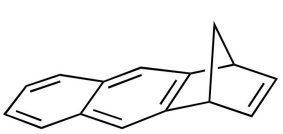

11

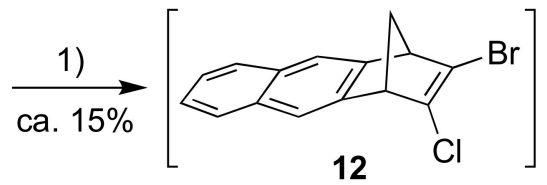

12

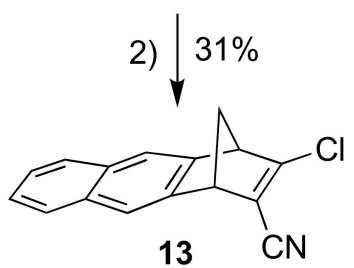

Scheme 4. Reagents and conditions: (1) i. $t$-BuOK, THF; ii. BuLi, $-84{ }^{\circ} \mathrm{C}$ to $-41{ }^{\circ} \mathrm{C}$; iii. $\mathrm{TsCl},-84{ }^{\circ} \mathrm{C}$; iv. BuLi, $-84{ }^{\circ} \mathrm{C}$ to $-41{ }^{\circ} \mathrm{C}$; v. $\mathrm{TsBr},-84^{\circ} \mathrm{C}$ to $\mathrm{rt}$; (2) $\mathrm{CuCN}, \mathrm{DMF}, 100{ }^{\circ} \mathrm{C}$.

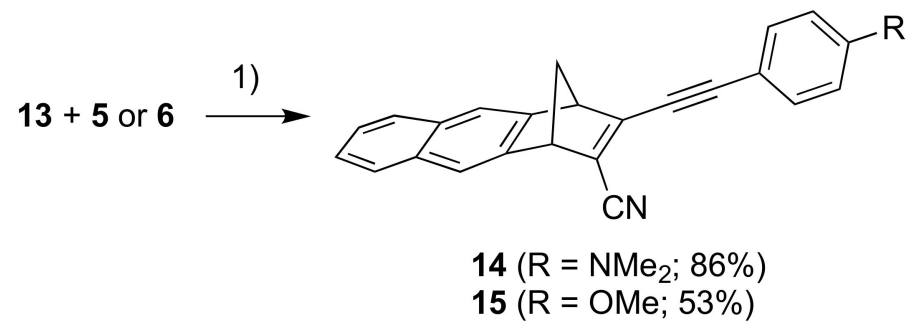

Scheme 5. Reagents and conditions:(1) $\mathrm{Pd}\left(\mathrm{PPh}_{3}\right)_{2} \mathrm{Cl}_{2}, \mathrm{CuI}, \mathrm{THF} / \mathrm{Et}_{3} \mathrm{~N}$.

For introducing a phenanthrene unit, we first had to develop a protocol for fusing this polycyclic aromatic hydrocarbon to NBD as shown in Scheme 6. First, 2,2'-dimethyl-1,1'-biphenyl (16) was converted into the tetrabromide $\mathbf{1 7}$ by radical bromination and, upon subsequent treatment with strong base, the dibromo-substituted phenanthrene 18 resulted. This compound was turned into the corresponding benzyne derivative that was reacted in a cycloaddition reaction with cyclopentadiene to give the NBD derivative 19. This compound was then converted into the bromo/chloro derivative 20 (isolated as an inseparable mixture with 19) that was subsequently converted into the cyano compound 21. Sonogashira couplings finally gave the donor-acceptor derivatives 22 and 23 as shown in Scheme 7.<smiles>Cc1ccccc1-c1ccccc1CC(C)C</smiles>

16<smiles>BrC(Br)c1ccccc1-c1ccccc1C(Br)Br</smiles>

17

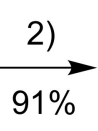<smiles>Brc1c(Br)c2ccccc2c2ccccc12</smiles>

18<smiles>CCC1=CC=CC1</smiles>

3) $45 \%$

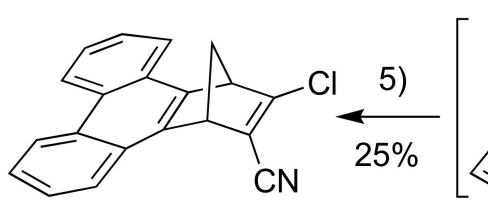

21

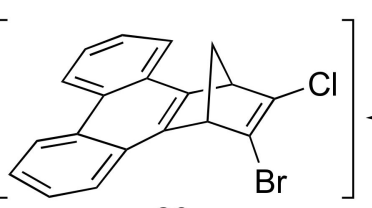

20

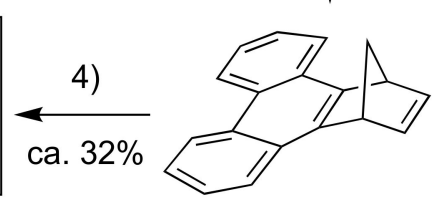

19

Scheme 6. Reagents and conditions: (1) 1-bromopyrrolidine-2,5-dione, benzoyl peroxide, $\mathrm{PhH}$, reflux; (2) $t$-BuOK, DMF, $0{ }^{\circ} \mathrm{C}$; (3) BuLi, PhMe; (4) i. $t$-BuOK, THF; ii. BuLi, $-84{ }^{\circ} \mathrm{C}$ to $-41{ }^{\circ} \mathrm{C}$; iii. $\mathrm{TsCl},-84{ }^{\circ} \mathrm{C}$; iv. $\mathrm{BuLi},-84{ }^{\circ} \mathrm{C}$ to $-41^{\circ} \mathrm{C}$; v. $\mathrm{TsBr},-84^{\circ} \mathrm{C}$ to rt; 5) $\mathrm{CuCN}, \mathrm{DMF}$. 


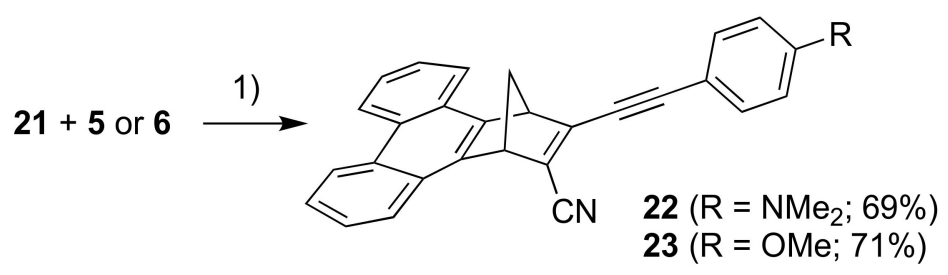

Scheme 7. Reagents and conditions: (1) $\mathrm{Pd}\left(\mathrm{PPh}_{3}\right)_{2} \mathrm{Cl}_{2}, \mathrm{CuI}, \mathrm{THF} / \mathrm{Et}_{3} \mathrm{~N}$.

\subsection{Optical and Switching Properties}

The UV-Vis absorption spectra of the new NBD derivatives are shown in Figure 2; Figure 3 and longest-wavelength absorption maxima are listed in Table 1. Comparison of compounds $\mathbf{8}$ and $\mathbf{1 5}$ as well as compounds $\mathbf{7}$ and $\mathbf{1 4}$ shows that it has little influence on the absorption spectra whether the NBD is benzo- or naphtho-fused. Instead, compounds $\mathbf{9}$ and $\mathbf{1 0}$ with expanded donor units exhibit significantly redshifted absorptions, owing to their significantly larger $\pi$-conjugated system. It is seen that the spectra are changed significantly when the fused aromatic group is changed for a phenanthrene unit in the case of 22 and 23.

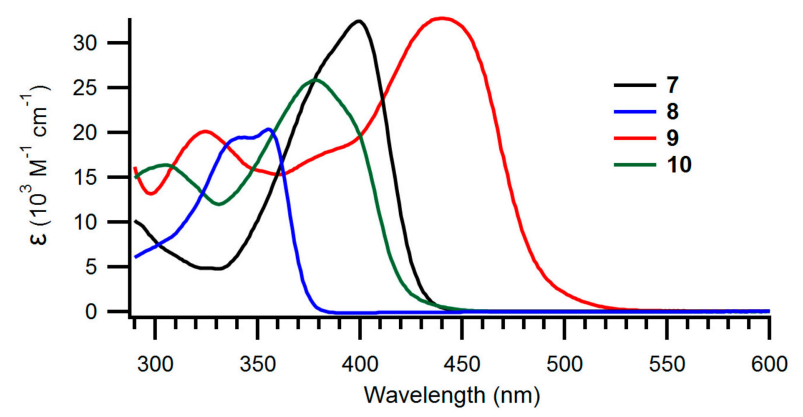

Figure 2. UV-Vis absorption spectra of benzo-fused NBDs 7-10 recorded in toluene.

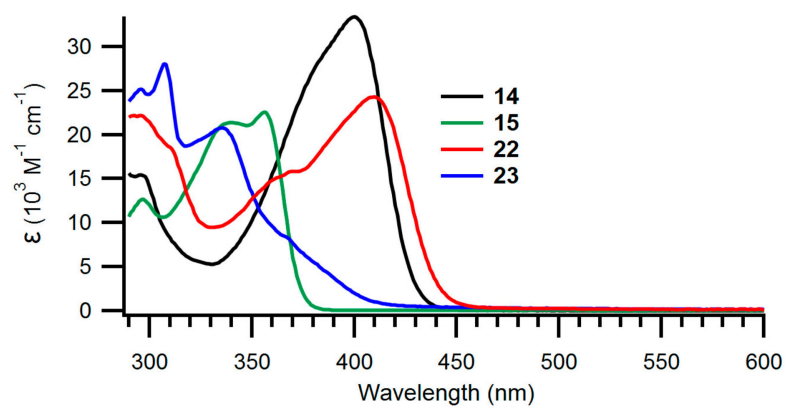

Figure 3. UV-Vis absorption spectra of naphtho- and phenanthro-fused NBDs 14, 15, 22 and 23 recorded in toluene.

Table 1. Longest-wavelength absorption maxima $\left(\lambda_{\max } / \mathrm{nm}\right)$ and molar absorptivities $\left(\varepsilon / 10^{3} \mathrm{M}^{-1} \mathrm{~cm}^{-1}\right)$ in brackets.

\begin{tabular}{cc}
\hline Compound & $\lambda_{\max } / \mathbf{n m}\left(\varepsilon / \mathbf{1 0}^{\mathbf{3}} \mathbf{M}^{\mathbf{- 1}} \mathbf{c m}^{\mathbf{- 1}}\right)$ \\
\hline $\mathbf{7}$ & $399(32.4)$ \\
$\mathbf{8}$ & $355(20.4)$ \\
$\mathbf{9}$ & $440(32.8)$ \\
$\mathbf{1 0}$ & $378(25.9)$ \\
$\mathbf{1 4}$ & $400(33.4)$ \\
$\mathbf{1 5}$ & $356(22.6)$ \\
$\mathbf{2 2}$ & $410(24.3)$ \\
$\mathbf{2 3}$ & $336(20.8)$ \\
\hline
\end{tabular}


The structures of compounds $\mathbf{9}$ and $\mathbf{1 0}$ were confirmed by HSQC, HMBC and NOE NMR spectroscopic analyses (see Supplementary Materials). The Z-configuration was assigned based on an NOE correlation between the vinylic proton and the closest ortho-proton on the phenyl group directly attached to the vinyl unit. By subjecting 9 and $\mathbf{1 0}$ to irradiation at their absorption maxima using a 450-W Xe lamp, the spectra changed as revealed in Figure 4; the intensity of the longest-wavelength absorption (slightly blueshifted) was found to decrease, while the intensity of the higher-energy absorption around $300 \mathrm{~nm}$ was found to increase. Conversions occurred with isosbestic points and by ${ }^{1} \mathrm{H}-\mathrm{NMR}$ spectroscopic analysis of compound 9 it was found that rather than NBD-to-QC photoisomerization, $Z$-to- $E$ isomerization occurred. After $22 \mathrm{~h}$ of irradiation at $440 \mathrm{~nm}$, a 1:1 ratio of $E$ and $Z$ isomers was obtained for compound 9 (Figure 5).
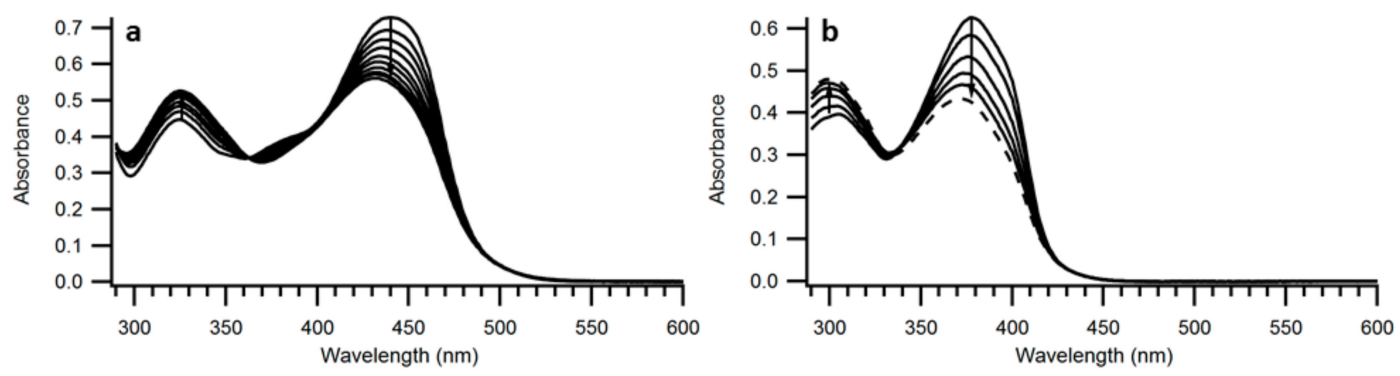

Figure 4. UV-Vis absorption spectra of (a) 9 in toluene during irradiation with 440-nm light, (b) 10 in toluene during irradiation with $378 \mathrm{~nm}$ light.

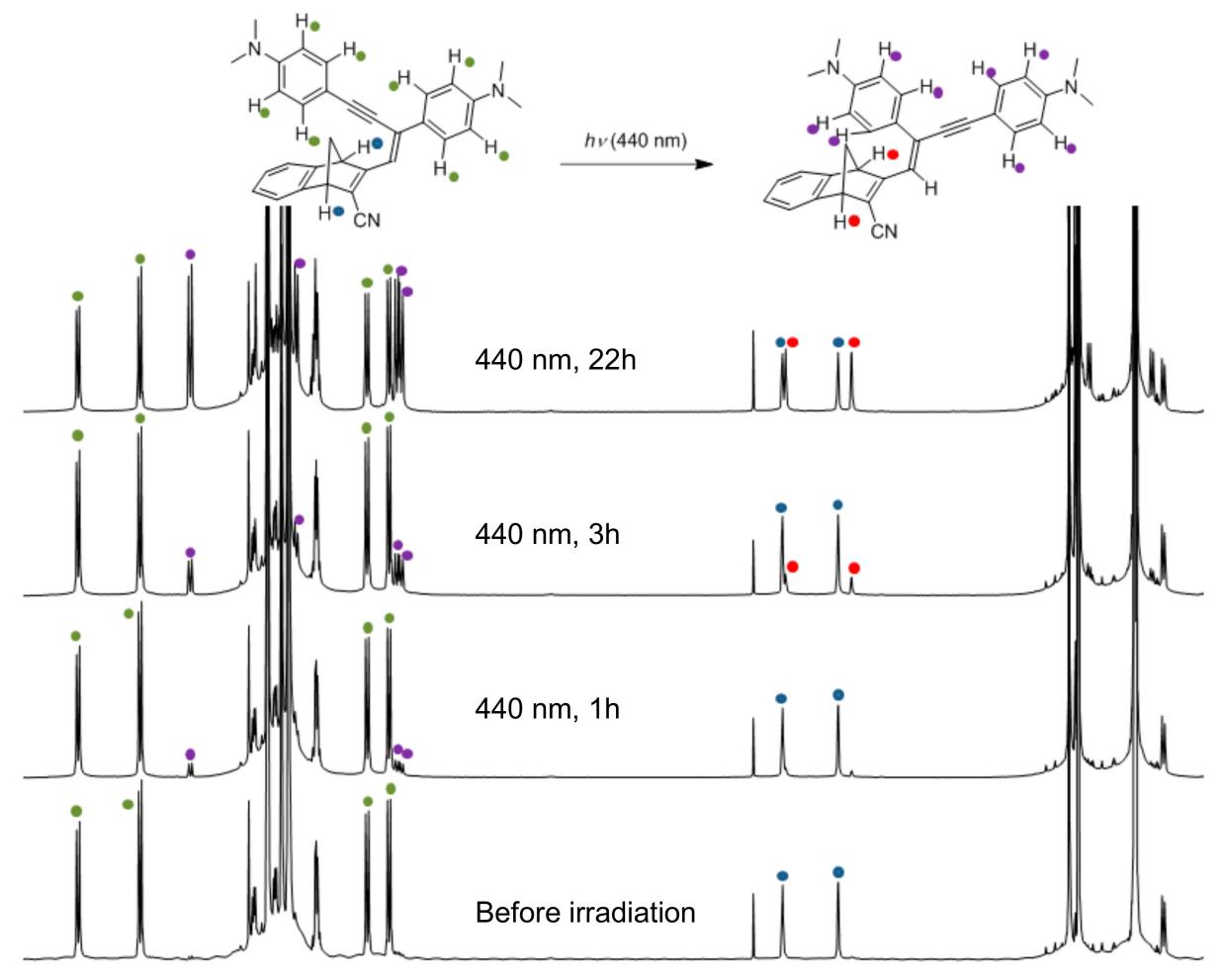

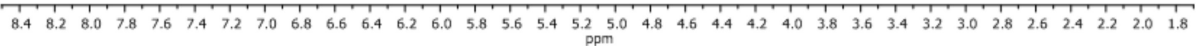

Figure 5. ${ }^{1} \mathrm{H}-\mathrm{NMR}$ Spectra (toluene- $d_{8}, 500 \mathrm{MHz}$ ) of 9 recorded after various times of irradiation (440 nm).

To investigate the switching properties of the benzo-fused systems $\mathbf{7}$ and $\mathbf{8}$, they were irradiated at the longest-wavelength absorption maxima with a $450 \mathrm{~W}$ Xe-lamp. After irradiation for up to $60 \mathrm{~min}$ no sign of isomerization was observed in both cases. Switching the light source to a broad-spectrum 
thin-layer chromatography (TLC) lamp (365 nm), only decomposition of the compounds was observed, verified by no backreaction occurring posterior to light irradiation. A more concentrated sample $(6 \mathrm{mM})$ of 7 in toluene was argon-flushed and irradiated with a $405 \mathrm{~nm}$ light emitting diode (LED). Following the reaction on TLC showed a complex mixture of decomposition products. For the two naphtho-fused NBDs 14 and 15, an absorbance decrease was observed after irradiation at the longest-wavelength absorption maxima with a 450-W Xe-lamp but no backreaction was seen posterior to irradiation. An NMR sample of the methoxy-substituted NBD 15 in $d_{8}$-toluene was irradiated at $356 \mathrm{~nm}$ but after $19 \mathrm{~h}$ this also resulted in a complex mixture according to TLC inspection and no QC characteristic signals were seen in the complex NMR spectrum of the mixture (See ESI). For the phenanthro-fused NBDs 22 and 23 once again no signs of isomerization were observed. For all the systems 7, 8, 14, 15, 22 and 23 low temperature UV-Vis experiments using a cryostat were performed to investigate whether the lack of observed NBD-to-QC photoconversion was caused by a rapid QC-to-NBD backreaction. Unfortunately, no signs of isomerization were observed even at temperatures down to $-60{ }^{\circ} \mathrm{C}$.

\subsection{Sensitized Switching Studies}

Previously, it has been found that unsubstituted norbornadiene can be converted to quadricyclane in presence of sensitizer [18]. We note that the compounds, 7, 8, 14 and 15 did not lead to the corresponding quadricyclanes during direct excitation at their maximum absorption wavelength. This could in principle be due to too low-lying S1 states of these compounds. One possible alternative could be to try to convert the compounds via their triplet excited states. Michler's ketone is a known triplet sensitizer that has been used for the conversion of other NBD compounds and therefore, the conversion of $\mathbf{2 2}$ and $\mathbf{2 3}$ with this photosensitizer was attempted. Compounds 22 and 23 were individually mixed in toluene with excess of sensitizer. Since the maximum absorption of Michler's ketone extends from $290 \mathrm{~nm}$ to $381 \mathrm{~nm}$, a $300 \mathrm{~nm}$ LED light source was used to irradiate the prepared samples. Unfortunately, no conversion was observed in both cases according to ${ }^{1} \mathrm{H}$ NMR spectroscopic analysis.

\section{Discussion}

We have in this work shown that the previously one-pot procedure for functionalization of norbornadiene at one double bond can conveniently be expanded to benzo-, naphtho- and phenanthro-fused norbornadienes. This expansion has allowed the synthesis of a selection of derivatives with donor-acceptor substituent groups. The identity of the fused aromatic has little influence on the longest-wavelength absorption maximum of the compounds; this absorption maximum is rather determined by the donor and acceptor groups at the other double bond. None of the new derivatives were able to undergo norbornadiene-to-quadricyclane photoisomerization, not even by the use of a photosensitizer; instead, photodegradations of the compounds occurred. Due to the experimental conditions, we cannot rule out that a short-lived QC form of the molecules exists but due to the time resolution of our experiments, we cannot assess this. For allowing the photoswitching event, it seems that the loss of aromaticity should be further decreased from that of the phenanthrene unit.

\section{Materials and Methods}

\subsection{General Methods}

THF used for coupling reactions was distilled over a $\mathrm{Na} /$ benzophenone couple or retrieved from an Innovative Technology PURESOLV ${ }^{\mathrm{TM}}$ solvent purification system of the model PS-MD-05. UV-Vis spectra were acquired using a Varian Cary 50 Bio spectrophotometer. UV-Vis spectroscopy experiments were performed using a quartz cuvette with a $1 \mathrm{~cm}$ path length coupled to a Peltier element for temperature control. Irradiation studies were performed using an ozone-free 450-W Xe lamp equipped with a monochromator, a broad spectrum TLC lamp (365 nm) or a Thorlabs $405 \mathrm{~nm}$ LED lamp of the model M405LP1. Thin-layer chromatography (TLC) was carried out using aluminum sheets precoated 
with silica gel. NMR spectra were acquired using a Bruker $500 \mathrm{MHz}$ instrument with a non-inverse cryo-probe or a Varian $400 \mathrm{MHz}$ instrument using the residual solvent peak as the reference $\left(\mathrm{CDCl}_{3}\right.$ : ${ }^{1} \mathrm{H} 7.26$ ppm $\left(\mathrm{CHCl}_{3}\right),{ }^{13} \mathrm{C} 77.16$ ppm. d8-Toluene: ${ }^{1} \mathrm{H} 2.090 \mathrm{ppm}$ (d7-toluene)). Mass spectra (HRMS) were acquired on an ESP-MALDI-FT-ICR spectrometer equipped with a $7 \mathrm{~T}$ magnet (calibration of the instrument was done with NaTFA cluster ions). Elemental analyses were performed at Department of Chemistry, University of Copenhagen. Purification by flash column chromatography was carried out on silica gel $\left(\mathrm{SiO}_{2}, 60 \AA, 40-63 \mu \mathrm{m}\right)$. When referring to petroleum spirit a technical grade with boiling point $40-65^{\circ} \mathrm{C}$ was used.

General assignments of ${ }^{1} \mathrm{H}-\mathrm{NMR}$ resonances: NBD bridgehead $\mathrm{C}\left(\mathrm{sp}^{3}\right)-\mathrm{H}$ signals are observed in the region 2.3-3.0 ppm when the NBD positions are differently substituted as a pair of signals (each integrating as $1 \mathrm{H}$ ) with apparent dt multiplicities (in principle, ddd with two similar coupling constants). NBD- $\mathrm{CH}_{2}$ protons are observed in the region 3.8-4.9 ppm as two multiplets (each $1 \mathrm{H}$ ). $\mathrm{N}\left(\mathrm{CH}_{3}\right)_{2}$ and $\mathrm{OCH}_{3}$ protons are observed as singlets at $3.0 \mathrm{ppm}(6 \mathrm{H})$ and 3.8-3.9 ppm (3H), respectively; for compounds 9 and 10, two singlets are observed (corresponding to two different $\mathrm{N}\left(\mathrm{CH}_{3}\right)_{2}$ and $\mathrm{OCH}_{3}$ units, respectively). Aromatic protons are seen at or above $6.6 \mathrm{ppm}$.

\subsection{Synthesis Protocols}

2-Bromo-3-chloro-1,4-dihydro-1,4-methanonaphthalene (2). To a solution of $t$-BuOK (4.88 g, $43.5 \mathrm{mmol})$ in anhydrous THF $(100 \mathrm{~mL})$ at $-84{ }^{\circ} \mathrm{C}$ were added $\mathbf{1}(7.09 \mathrm{~g}, 49.9 \mathrm{mmol})$ followed by $n$-BuLi (2.5 M in hexanes, $16.8 \mathrm{~mL}, 42.0 \mathrm{mmol}$ ) over the course of $30 \mathrm{~min}$. The mixture was stirred for $1 \mathrm{~h}$ at $-41^{\circ} \mathrm{C}$, before it was cooled to $-84{ }^{\circ} \mathrm{C}$ and $p$-toluenesulfonyl chloride $(8.03 \mathrm{~g}, 42.1 \mathrm{mmol})$ was added and the mixture was stirred at $-84{ }^{\circ} \mathrm{C}$ for $30 \mathrm{~min}$. Once again $n$-BuLi $(2.5 \mathrm{M}$ in hexanes, $16.8 \mathrm{~mL}, 42.0 \mathrm{mmol}$ ) was added over the course of $30 \mathrm{~min}$, before the mixture was stirred at $-41^{\circ} \mathrm{C}$ for $1 \mathrm{~h}$. The mixture was cooled to $-84^{\circ} \mathrm{C}$ and $p$-toluenesulfonyl bromide $(9.95 \mathrm{~g}, 42.3 \mathrm{mmol})$ was added. The mixture was stirred for $20 \mathrm{~min}$ at $-84^{\circ} \mathrm{C}$, before it was allowed to reach rt. The reaction mixture was quenched with $\mathrm{H}_{2} \mathrm{O}(400 \mathrm{~mL})$, the phases were separated and the aqueous phase was extracted with $\mathrm{Et}_{2} \mathrm{O}(3 \times 200 \mathrm{~mL})$. The combined organic phases were dried over $\mathrm{Na}_{2} \mathrm{SO}_{4}$, filtered and concentrated in vacuo. The crude mixture was redissolved in hexane, poured through a plug of silica $(43-60 \mu \mathrm{m})$ and concentrated in vacuo. The mixture was concentrated by a stream of nitrogen affording 2 as a white solid of sufficient purity for further reaction $(6.78 \mathrm{~g}, 54 \%) .{ }^{1} \mathrm{H} \mathrm{NMR}(400 \mathrm{MHz}$, $\left.\mathrm{CDCl}_{3}\right): \delta=7.34(\mathrm{dd}, J=5.2,3.0 \mathrm{~Hz}, 2 \mathrm{H}), 7.05(\mathrm{dd}, J=5.2,3.0 \mathrm{~Hz}, 2 \mathrm{H}), 3.92(\mathrm{~m}, 1 \mathrm{H}), 3.86(\mathrm{~m}, 1 \mathrm{H}), 2.74$ $(\mathrm{dd}, J=7.4,1.8 \mathrm{~Hz}, 1 \mathrm{H}), 2.40(\mathrm{dd}, J=7.4,1.8 \mathrm{~Hz}, 1 \mathrm{H}) \mathrm{ppm} .{ }^{13} \mathrm{C} \mathrm{NMR}\left(100 \mathrm{MHz}, \mathrm{CDCl}_{3}\right): \delta=148.31$, $147.86,144.49,143.13,129.32,125.67,125.64,122.19,66.90,58.14,57.14$ ppm. HR-MS (APCI ${ }^{+}$FT-ICR): $m / z=254.95769\left[\mathrm{M}+\mathrm{H}^{+}\right]$, calcd. for $\left[\mathrm{C}_{11} \mathrm{H}_{9}{ }^{79} \mathrm{BrCl}^{+}\right]: m / z=254.95707$.

3-Chloro-1,4-dihydro-1,4-methanonaphthalene-2-carbonitrile (3). To an argon flushed solution of $2(6.00 \mathrm{~g}, 23.5 \mathrm{mmol})$ in DMF $(80 \mathrm{~mL})$ was added CuCN $(1.88 \mathrm{~g}, 21.0 \mathrm{mmol})$ and the mixture was heated to $105^{\circ} \mathrm{C}$ for $15 \mathrm{~h}$. The mixture was allowed to reach $\mathrm{rt}$, before it was poured into saturated aqueous $\mathrm{Na}_{2} \mathrm{CO}_{3}(200 \mathrm{~mL})$ and extracted with $\mathrm{Et}_{2} \mathrm{O}(3 \times 300 \mathrm{~mL})$. The combined organic phases were washed with water $(2 \times 400 \mathrm{~mL})$ and brine $(2 \times 400 \mathrm{~mL})$, dried over $\mathrm{Na}_{2} \mathrm{SO}_{4}$, filtered and concentrated in vacuo. The crude mixture was purified by flash column chromatography $\left(30 \% \mathrm{CH}_{2} \mathrm{Cl}_{2} /\right.$ heptane to $\left.100 \% \mathrm{CH}_{2} \mathrm{Cl}_{2}\right)$ affording 3 as an off-white solid $(2.20 \mathrm{~g}, 46 \%)$ along with $4(326 \mathrm{mg}, 7 \%)$. Compound 3: $R_{f}\left(50 \% \mathrm{CH}_{2} \mathrm{Cl}_{2} /\right.$ petroleum spirit $)=0.47$. IR: 3070, 3051, 3022, 2990, 2950, 2874, 2215, $1589 \mathrm{~cm}^{-1}$. ${ }^{1} \mathrm{H}$ NMR $\left(400 \mathrm{MHz}, \mathrm{CDCl}_{3}\right): \delta=7.42-7.33(\mathrm{~m}, 2 \mathrm{H}), 7.15-7.03(\mathrm{~m}, 2 \mathrm{H}), 4.18(\mathrm{~m}, 1 \mathrm{H}), 3.96(\mathrm{~m}, 1 \mathrm{H}), 2.72$ $(\mathrm{dt}, J=7.9,1.7 \mathrm{~Hz}, 1 \mathrm{H}), 2.45(\mathrm{dt}, J=7.9,1.7 \mathrm{~Hz}, 1 \mathrm{H}) \mathrm{ppm} .{ }^{13} \mathrm{C} \mathrm{NMR}(100 \mathrm{MHz}, \mathrm{CDCl}): \delta=164.18$, $147.36,145.79,126.54,126.13,123.15,122.75,121.09,114.12,68.22,58.13,53.63$ ppm. HR-MS (ESI ${ }^{+}$ FT-ICR): $m / z=202.04186[\mathrm{M}+\mathrm{H}+]$, calcd. for $\left[\mathrm{C}_{12} \mathrm{H}_{9} \mathrm{ClN}^{+}\right]: \mathrm{m} / z=202.04180$. Compound 4: ${ }^{1} \mathrm{H} \mathrm{NMR}$ $\left(400 \mathrm{MHz} \mathrm{CDCl}_{3}\right): \delta=7.42(\mathrm{dd}, J=5.3,3.1 \mathrm{~Hz}, 2 \mathrm{H}), 7.13(\mathrm{dd}, J=5.3,3.1 \mathrm{~Hz}, 2 \mathrm{H}), 4.32(\mathrm{t}, J=1.6 \mathrm{~Hz}$, 2H), $2.70(\mathrm{dd}, J=8.4,1.6 \mathrm{~Hz}, 1 \mathrm{H}), 2.53(\mathrm{dd}, J=8.4,1.6 \mathrm{~Hz}, 1 \mathrm{H}) \mathrm{ppm} .{ }^{13} \mathrm{C} \mathrm{NMR}\left(126 \mathrm{MHz}, \mathrm{CDCl}_{3}\right): \delta=$ $144.87,140.47,126.85,123.74,112.84,70.06,54.86$ ppm. HR-MS (ESI ${ }^{+}$FT-ICR): $m / z=193.07619\left[\mathrm{M}^{+} \mathrm{H}^{+}\right]$, 
calcd. for $\left[\mathrm{C}_{13} \mathrm{H}_{9} \mathrm{~N}_{2}{ }^{+}\right]: \mathrm{m} / z=193.07602$. EA $\left(\mathrm{C}_{13} \mathrm{H}_{8} \mathrm{~N}_{2}\right)$ : calcd. C 81.23, $\mathrm{H} 4.20, \mathrm{~N} 14.57$; found $\mathrm{C} 80.86$, H 4.51, N 15.00 .

3-((4-(Dimethylamino)phenyl)ethynyl)-1,4-dihydro-1,4-methanonaphthalene-2-carbonitrile

(7). To an argon flushed solution of $3(200 \mathrm{mg}, 0.992 \mathrm{mmol})$ and 4-ethynyl- $\mathrm{N}, \mathrm{N}$-dimethylaniline (5) $(156 \mathrm{mg}, 1.07 \mathrm{mmol})$ in THF $(20 \mathrm{~mL})$ and $\mathrm{Et}_{3} \mathrm{~N}(12 \mathrm{~mL})$ were added CuI $(18 \mathrm{mg}, 0.095 \mathrm{mmol})$ and $\mathrm{Pd}\left(\mathrm{PPh}_{3}\right)_{2} \mathrm{Cl}_{2}(71 \mathrm{mg}, 0.10 \mathrm{mmol})$ and the mixture was stirred overnight. The reaction mixture was poured through a plug of silica $\left(43-60 \mu \mathrm{m}, \mathrm{CH}_{2} \mathrm{Cl}_{2}\right)$ and concentrated in vacuo. The residue was subjected to flash column chromatography $\left(60 \% \mathrm{CH}_{2} \mathrm{Cl}_{2} /\right.$ hexane) affording 7 as a yellow solid $(238 \mathrm{mg}$, $77 \%) . R_{f}\left(60 \% \mathrm{CH}_{2} \mathrm{Cl}_{2} /\right.$ hexane $)=0.38 .{ }^{1} \mathrm{H} \mathrm{NMR}\left(400 \mathrm{MHz}, \mathrm{CDCl}_{3}\right): \delta=7.41-7.33(\mathrm{~m}, 2 \mathrm{H}), 7.38(\mathrm{~d}, J=$ $9.1 \mathrm{~Hz}, 2 \mathrm{H}), 7.11-7.00(\mathrm{~m}, 2 \mathrm{H}), 6.62(\mathrm{~d}, J=9.1 \mathrm{~Hz}, 2 \mathrm{H}), 4.16(\mathrm{~m}, 1 \mathrm{H}), 4.11(\mathrm{~m}, 1 \mathrm{H}), 3.01(\mathrm{~s}, 6 \mathrm{H}), 2.59$ $(\mathrm{dt}, J=7.9,1.7 \mathrm{~Hz}, 1 \mathrm{H}), 2.41(\mathrm{dt}, J=7.9,1.7 \mathrm{~Hz}, 1 \mathrm{H}) \mathrm{ppm} .{ }^{13} \mathrm{C} \mathrm{NMR}\left(100 \mathrm{MHz}, \mathrm{CDCl}_{3}\right): \delta=153.61$, $151.06,147.86,147.02,133.67,126.03,125.83,124.45,123.00,122.49,116.73,111.69,111.04,108.22,82.26$, 67.96, 57.02, 53.49, 40.20 ppm. HR-MS (ESI FT-ICR): $\mathrm{m} / \mathrm{z}=311.1552\left[\mathrm{M}+\mathrm{H}^{+}\right]$, calcd. for $\left[\mathrm{C}_{22} \mathrm{H}_{19} \mathrm{~N}_{2}{ }^{+}\right]$: $m / z=311.1543$.

Compound 8. To a solution of ((4-methoxyphenyl)ethynyl)trimethylsilane ( $230 \mathrm{mg}, 1.13 \mathrm{mmol})$ in THF and $\mathrm{MeOH}(20 \mathrm{~mL}, 1: 1, v / v)$ was added $\mathrm{K}_{2} \mathrm{CO}_{3}(594 \mathrm{mg}, 4.30 \mathrm{mmol})$ and the mixture was stirred at $\mathrm{rt}$ for $1 \mathrm{~h}$. The mixture containing 6 was poured through a plug of silica ( $\left.40-63 \mu \mathrm{m}, \mathrm{CH}_{2} \mathrm{Cl}_{2}\right)$, almost concentrated in vacuo zand then THF $(50 \mathrm{~mL})$ was added and the mixture was concentrated to approx. $10 \mathrm{~mL}$. Then $3(207 \mathrm{mg}, 1.03 \mathrm{mmol})$ and $\mathrm{Et}_{3} \mathrm{~N}(10 \mathrm{~mL})$ were added and the mixture was flushed with argon. $\mathrm{Pd}\left(\mathrm{PPh}_{3}\right)_{2} \mathrm{Cl}_{2}(85 \mathrm{mg}, 0.12 \mathrm{mmol})$ and $\mathrm{CuI}(17 \mathrm{mg}, 89 \mu \mathrm{mol})$ were added and the mixture was stirred for $19 \mathrm{~h}$ at rt. The reaction mixture was poured through a plug of silica $(40-63 \mu \mathrm{m}$, $\mathrm{CH}_{2} \mathrm{Cl}_{2}$ ) and concentrated in vacuo. The residue was subjected to flash column chromatography (50\% $\mathrm{CH}_{2} \mathrm{Cl}_{2}$ /heptane to $70 \% \mathrm{CH}_{2} \mathrm{Cl}_{2}$ /heptane) affording 8 as a slightly brown semicrystalline oil (222 $\mathrm{mg}$, $73 \%) . R_{f}\left(70 \% \mathrm{CH}_{2} \mathrm{Cl}_{2} /\right.$ heptane $)=0.45 .{ }^{1} \mathrm{H} \mathrm{NMR}\left(500 \mathrm{MHz}, \mathrm{CDCl}_{3}\right): \delta=7.45(\mathrm{~d}, J=8.9 \mathrm{~Hz}, 2 \mathrm{H})$, 7.41-7.37 (m, 1H), 7.37-7.34 (m, 1H), 7.09-7.04 (m, 2H), $6.87(\mathrm{~d}, J=8.9 \mathrm{~Hz}, 2 \mathrm{H}), 4.17(\mathrm{~m}, 1 \mathrm{H}), 4.12(\mathrm{~m}$, $1 \mathrm{H}), 3.83(\mathrm{~s}, 3 \mathrm{H}), 2.61(\mathrm{dt}, J=8.0,1.8 \mathrm{~Hz}, 1 \mathrm{H}), 2.42(\mathrm{dt}, J=8.0,1.8 \mathrm{~Hz}, 1 \mathrm{H}) \mathrm{ppm} .{ }^{13} \mathrm{C} \mathrm{NMR}(126 \mathrm{MHz}$, $\left.\mathrm{CDCl}_{3}\right): \delta=160.91,153.27,147.60,146.87,133.85,126.80,126.14,125.97,123.07,122.67,116.26,114.33$,

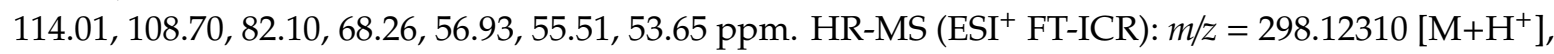
calcd. for $\left[\mathrm{C}_{21} \mathrm{H}_{16} \mathrm{NO}^{+}\right]: m / z=298.12264$. $\mathrm{EA}\left(\mathrm{C}_{21} \mathrm{H}_{15} \mathrm{NO}\right)$ : calcd. $\mathrm{C} 84.82, \mathrm{H} 5.08, \mathrm{~N} 4.71$; found $\mathrm{C}$ 84.29, H 5.20, N 4.85 .

Compound 9. To an argon flushed solution of 3 (221 $\mathrm{mg}, 1.10 \mathrm{mmol})$ and 4-ethynyl- $\mathrm{N}, \mathrm{N}$-dimethylaniline (5) $(246 \mathrm{mg}, 1.69 \mathrm{mmol})$ in THF $(20 \mathrm{~mL})$ and $\mathrm{Et}_{3} \mathrm{~N}(12 \mathrm{~mL})$ were added $\mathrm{CuI}(20 \mathrm{mg}, 0.11 \mathrm{mmol})$ and $\mathrm{Pd}\left(\mathrm{PPh}_{3}\right)_{2} \mathrm{Cl}_{2}(77 \mathrm{mg}, 0.11 \mathrm{mmol})$ and the mixture was stirred for $2 \mathrm{~h}$. More 4-ethynyl- $N, N$-dimethylaniline $(181 \mathrm{mg}, 1.25 \mathrm{mmol})$ was added and the mixture was stirred overnight. The reaction mixture was poured through a plug of silica (43-60 $\mu \mathrm{m}, \mathrm{CH}_{2} \mathrm{Cl}_{2}$ ) and concentrated in vacuo. The residue was subjected to flash column chromatography $\left(80 \% \mathrm{CH}_{2} \mathrm{Cl}_{2} /\right.$ hexane to $\left.100 \% \mathrm{CH}_{2} \mathrm{Cl}_{2}\right)$ affording 9 as a red solid $(363 \mathrm{mg}$, $73 \%) . R_{f}\left(80 \% \mathrm{CH}_{2} \mathrm{Cl}_{2} /\right.$ heptane $)=0.28$. IR = 3047, 2986, 2941, 2896, 2862, 2804, 2192, 2208sh, 2177sh, 1606, 1553, 1557sh, $1517 \mathrm{~cm}^{-1} .{ }^{1} \mathrm{H} \mathrm{NMR}(400 \mathrm{MHz}$, $\left.\mathrm{CDCl}_{3}\right): \delta=8.04(\mathrm{~d}, J=9.1 \mathrm{~Hz}, 2 \mathrm{H}), 7.55(\mathrm{~d}, J=9.0 \mathrm{~Hz}, 2 \mathrm{H}), 7.42-7.33(\mathrm{~m}, 2 \mathrm{H}), 7.15(\mathrm{~s}, 1 \mathrm{H}), 7.09-6.98$ $(\mathrm{m}, 2 \mathrm{H}), 6.70(\mathrm{~d}, J=9.1 \mathrm{~Hz}, 2 \mathrm{H}), 6.69(\mathrm{~d}, J=9.0 \mathrm{~Hz}, 2 \mathrm{H}), 4.50(\mathrm{~m}, 1 \mathrm{H}), 4.18(\mathrm{~m}, 1 \mathrm{H}), 3.04(\mathrm{~s}, 6 \mathrm{H}), 2.99$ $(\mathrm{s}, 6 \mathrm{H}), 2.54(\mathrm{dt}, J=7.8,1.7 \mathrm{~Hz}, 1 \mathrm{H}), 2.35(\mathrm{dd}, J=7.8,1.7 \mathrm{~Hz}, 1 \mathrm{H}) \mathrm{ppm} .{ }^{13} \mathrm{C} \mathrm{NMR}\left(100 \mathrm{MHz}, \mathrm{CDCl}_{3}\right)$ : $\delta=168.37,151.12,150.35,149.32,147.32,136.99,132.67,131.80,125.60,125.49,124.03,122.45,122.07$, $118.19,115.18,112.04,111.59,111.34,110.32,99.08,84.78,65.77,55.04,53.25,40.34,40.24$ ppm. HR-MS (ESI ${ }^{+}$FT-ICR): $\mathrm{m} / \mathrm{z}=456.2438\left[\mathrm{M}+\mathrm{H}^{+}\right]$, calcd. for $\left[\mathrm{C}_{32} \mathrm{H}_{30} \mathrm{~N}_{3}{ }^{+}\right]: \mathrm{m} / \mathrm{z}=456.2434$.

Compound 10. To a solution of ((4-methoxyphenyl)ethynyl)trimethylsilane ( $649 \mathrm{mg}, 3.18 \mathrm{mmol})$ in THF/MeOH $(20 \mathrm{~mL}, 1: 1, v / v)$ was added $\mathrm{K}_{2} \mathrm{CO}_{3}(1.56 \mathrm{~g}, 11.3 \mathrm{mmol})$ and the mixture was stirred at $\mathrm{rt}$ for $2 \mathrm{~h}$. The mixture was poured through a plug of silica $\left(43-60 \mu \mathrm{m}, \mathrm{CH}_{2} \mathrm{Cl}_{2}\right)$ and concentrated in vacuo to provide 6 . THF $(20 \mathrm{~mL}), \mathrm{Et}_{3} \mathrm{~N}(12 \mathrm{~mL})$ and $3(180 \mathrm{mg}, 0.893 \mu \mathrm{mol})$ were added and the mixture was flushed with argon. $\mathrm{CuI}(17 \mathrm{mg}, 0.089 \mathrm{mmol})$ and $\mathrm{Pd}\left(\mathrm{PPh}_{3}\right)_{2} \mathrm{Cl}_{2}(69 \mathrm{mg}, 0.098 \mathrm{mmol})$ were added and the mixture was stirred at $\mathrm{rt}$ for $23 \mathrm{~h}$. The reaction mixture was poured through a plug 
of silica (43-60 $\mu \mathrm{m}, \mathrm{CH}_{2} \mathrm{Cl}_{2}$ ) and concentrated in vacuo. The residue was subjected to flash column chromatography $\left(70 \% \mathrm{CH}_{2} \mathrm{Cl}_{2} /\right.$ hexane to $90 \% \mathrm{CH}_{2} \mathrm{Cl}_{2}$ /hexane) affording $\mathbf{1 0}$ as a yellow solid (303 $\mathrm{mg}$, $79 \%) . R_{f}\left(80 \% \mathrm{CH}_{2} \mathrm{Cl}_{2} /\right.$ heptane $)=0.41 .{ }^{1} \mathrm{H} \mathrm{NMR}\left(400 \mathrm{MHz}, \mathrm{CDCl}_{3}\right): \delta=8.03(\mathrm{~d}, J=8.9 \mathrm{~Hz}, 2 \mathrm{H}), 7.59$ $(\mathrm{d}, J=8.9 \mathrm{~Hz}, 2 \mathrm{H}), 7.43-7.35(\mathrm{~m}, 2 \mathrm{H}), 7.19(\mathrm{~s}, 1 \mathrm{H}), 7.11-7.00(\mathrm{~m}, 2 \mathrm{H}), 6.94(\mathrm{~d}, J=8.9 \mathrm{~Hz}, 2 \mathrm{H}), 6.90(\mathrm{~d}, J=$ $8.9 \mathrm{~Hz}, 2 \mathrm{H}), 4.48(\mathrm{~m}, 1 \mathrm{H}), 4.21(\mathrm{~m}, 1 \mathrm{H}), 3.86(\mathrm{~s}, 3 \mathrm{H}), 3.83(\mathrm{~s}, 3 \mathrm{H}), 2.56(\mathrm{dt}, J=7.9,1.7 \mathrm{~Hz}, 1 \mathrm{H}), 2.38(\mathrm{dt}, J$ $=7.9,1.7 \mathrm{~Hz}, 1 \mathrm{H}) \mathrm{ppm} .{ }^{13} \mathrm{C} \mathrm{NMR}\left(100 \mathrm{MHz}, \mathrm{CDCl}_{3}\right): \delta=167.72,160.87,160.14,148.98,147.04,136.88$, 133.20, 131.74, 128.52, 125.79, 125.68, 122.48, 122.31, 117.79, 117.62, 115.13, 114.29, 114.06, 113.84, 98.10, 84.59, 66.14, 55.53, 55.46, 55.20, 53.21 ppm. HR-MS (ESI ${ }^{+}$FT-ICR): $\mathrm{m} / \mathrm{z}=430.1811$ [M+H $\left.{ }^{+}\right]$, calcd. for $\left[\mathrm{C}_{30} \mathrm{H}_{24} \mathrm{NO}_{2}{ }^{+}\right]: m / z=430.1802$. EA $\left(\mathrm{C}_{30} \mathrm{H}_{23} \mathrm{NO}_{2}\right)$ : calcd. C 83.89, $\mathrm{H} 5.40, \mathrm{~N}$ 3.26; found C 83.34, $\mathrm{H}$ 5.40, N 3.35 .

2-Bromo-3-chloro-1,4-dihydro-1,4-methanoanthracene (12). A solution of potassium tert-butoxide $(4.53 \mathrm{~g}, 40.4 \mathrm{mmol})$ in anhydrous THF $(180 \mathrm{~mL})$ was cooled to $-78{ }^{\circ} \mathrm{C}$, before $11(9.32 \mathrm{~g}$, $48.5 \mathrm{mmol})$ was added followed by $n$-BuLi $(16.16 \mathrm{~mL}, 2.5 \mathrm{M}, 40.41 \mathrm{mmol})$. The temperature was elevated to $-41^{\circ} \mathrm{C}$ and the mixture was stirred for $1 \mathrm{~h}$. The reaction mixture was cooled to $-78^{\circ} \mathrm{C}$ before $p$-toluenesulfonyl chloride $(7.71 \mathrm{~g}, 40.4 \mathrm{mmol})$ was added. The mixture was stirred for $30 \mathrm{~min}$ at $-78^{\circ} \mathrm{C}$; then $n$-BuLi $(16.16 \mathrm{~mL}, 2.5 \mathrm{M}, 40.41 \mathrm{mmol})$ was added, the temperature was elevated to $-41{ }^{\circ} \mathrm{C}$ and the mixture was stirred for $1 \mathrm{~h}$. The mixture was once again cooled to $-78{ }^{\circ} \mathrm{C}$ before $p$-toluenesulfonyl bromide $(9.63 \mathrm{~g}, 41.0 \mathrm{mmol})$ was added and the mixture was stirred for $15 \mathrm{~min}$. The reaction mixture was heated to rt using a water bath, poured into water $(300 \mathrm{~mL})$ and extracted with diethyl ether $(3 \times 200 \mathrm{~mL})$. The combined organic phases were washed with water $(2 \times$ $400 \mathrm{~mL}$ ) and brine $(400 \mathrm{~mL})$, dried over $\mathrm{Na}_{2} \mathrm{SO}_{4}$, filtered and concentrated in vacuo. Flash column chromatography (petroleum spirit) furnished $\mathbf{1 2}$ (estimated yield of ca. 15\%) and $\mathbf{1 1}$ as a 41:59 mixture (based on NMR integration) (3.40 g). The mixture of $\mathbf{1 2}$ and $\mathbf{1 1}$ was used in the next step without further purification.

3-Chloro-1,4-dihydro-1,4-methanoanthracene-2-carbonitrile (13). To an argon-flushed solution of the mixture of $\mathbf{1 1}$ and $\mathbf{1 2}(3.14 \mathrm{~g})$ in DMF $(40 \mathrm{~mL})$ was added $\mathrm{CuCN}(435 \mathrm{mg}, 4.86 \mathrm{mmol})$ and the mixture was heated to $100{ }^{\circ} \mathrm{C}$ and stirred for 10h. The mixture was allowed to cool to rt before it was poured into saturated aqueous sodium carbonate $(200 \mathrm{~mL})$ and extracted with diethyl ether $(3 \times 150$ $\mathrm{mL})$. The combined organic phases were washed with water $(3 \times 200 \mathrm{~mL})$ and brine $(200 \mathrm{~mL})$, dried over $\mathrm{Na}_{2} \mathrm{SO}_{4}$, filtered and concentrated in vacuo. Flash column chromatography $\left(30 \% \mathrm{CH}_{2} \mathrm{Cl}_{2} /\right.$ heptane to $50 \% \mathrm{CH}_{2} \mathrm{Cl}_{2}$ /heptane) afforded 13 as a white solid $(415 \mathrm{mg}, 31 \%)$. IR $=3076,3063,3048,2998,2953$, 2217, 1591, 1509sh, $1506 \mathrm{~cm}^{-1} .{ }^{1} \mathrm{H}$ NMR $\left(400 \mathrm{MHz}, \mathrm{CDCl}_{3}\right): \delta=7.80-7.73(\mathrm{~m}, 4 \mathrm{H}), 7.53-7.43(\mathrm{~m}, 2 \mathrm{H})$, $4.27(\mathrm{~m}, 1 \mathrm{H}), 4.07(\mathrm{~m}, 1 \mathrm{H}), 2.76(\mathrm{dt}, J=8.3,1.7 \mathrm{~Hz}, 1 \mathrm{H}), 2.45(\mathrm{dt}, J=8.3,1.7 \mathrm{~Hz}, 1 \mathrm{H}) \mathrm{ppm} .{ }^{13} \mathrm{C} \mathrm{NMR}$ $\left(100 \mathrm{MHz}, \mathrm{CDCl}_{3}\right): \delta=162.47,143.13,141.78,132.56,132.30,128.18,128.11,126.59,126.47,121.97$, 121.32, 120.40, 113.96, 64.72, 57.33, 52.83 ppm. HR-MS (ESI ${ }^{+}$FT-ICR): $m / z=252.05767\left[\mathrm{M}+\mathrm{H}^{+}\right]$, calcd. for $\left[\mathrm{C}_{16} \mathrm{H}_{11} \mathrm{ClN}^{+}\right]: m / z=252.05745$. EA $\left(\mathrm{C}_{16} \mathrm{H}_{10} \mathrm{ClN}\right)$ : calcd. C 76.35, $\mathrm{H} 4.00, \mathrm{~N} 5.56$; found $\mathrm{C} 76.21, \mathrm{H}$ 4.12, N 5.71 .

3-((4-(Dimethylamino)phenyl)ethynyl)-1,4-dihydro-1,4-methanoanthracene-2-carbonitrile

(14). To an argon flushed solution of $\mathbf{1 3}(151 \mathrm{mg}, 0.600 \mathrm{mmol})$ and 4-ethynyl- $N, N$-dimethylaniline (5) (95 mg, $0.65 \mathrm{mmol})$ in THF/Et $3 \mathrm{~N}(20 \mathrm{~mL}, 1: 1, v / v)$ were added CuI $(12 \mathrm{mg}, 63 \mu \mathrm{mol})$ and $\mathrm{Pd}\left(\mathrm{PPh}_{3}\right)_{2} \mathrm{Cl}_{2}$ ( $44 \mathrm{mg}, 63 \mu \mathrm{mol}$ ) and the mixture was stirred at $\mathrm{rt}$ for $4 \mathrm{~h}$. The reaction mixture was poured through a plug of silica ( $43-60 \mu \mathrm{m}, \mathrm{CH}_{2} \mathrm{Cl}_{2}$ ) and concentrated in vacuo. The crude mixture was purified by flash column chromatography ( $50 \% \mathrm{CH}_{2} \mathrm{Cl}_{2}$ /heptane) affording 14 as a yellow solid (186 $\left.\mathrm{mg}, 86 \%\right) . R_{f}(50 \%$ $\mathrm{CH}_{2} \mathrm{Cl}_{2}$ /heptane $)=0.13 .{ }^{1} \mathrm{H}$ NMR $\left(400 \mathrm{MHz}, \mathrm{CDCl}_{3}\right): \delta=7.80-7.69(\mathrm{~m}, 4 \mathrm{H}), 7.49-7.39(\mathrm{~m}, 2 \mathrm{H}), 7.38(\mathrm{~d}$, $J=9.1 \mathrm{~Hz}, 2 \mathrm{H}), 6.61(\mathrm{~d}, J=9.1 \mathrm{~Hz}, 2 \mathrm{H}), 4.25(\mathrm{~m}, 1 \mathrm{H}), 4.21(\mathrm{~m}, 1 \mathrm{H}), 3.00(\mathrm{~s}, 6 \mathrm{H}), 2.64(\mathrm{dt}, J=8.3,1.7$ $\mathrm{Hz}, 1 \mathrm{H}), 2.40(\mathrm{dd}, J=8.3,1.7 \mathrm{~Hz}, 1 \mathrm{H}) \mathrm{ppm} .{ }^{13} \mathrm{C} \mathrm{NMR}\left(100 \mathrm{MHz}, \mathrm{CDCl}_{3}\right): \delta=152.19,151.09,143.97$, 143.25, 133.74, 132.53, 132.40, 128.08, 128.01, 126.16, 126.08, 123.45, 121.55, 120.86, 116.54, 111.68, 110.66, $108.13,82.18,64.52,56.17,52.65,40.19$ ppm. HR-MS (ESI ${ }^{+}$FT-ICR): $m / z=361.17004\left[\mathrm{M}+\mathrm{H}^{+}\right]$, calcd. for $\left[\mathrm{C}_{26} \mathrm{H}_{21} \mathrm{~N}_{2}{ }^{+}\right]: m / z=361.16993$. 
3-((4-Methoxyphenyl)ethynyl)-1,4-dihydro-1,4-methanoanthracene-2-carbonitrile (15). To a solution of ((4-methoxyphenyl)ethynyl)trimethylsilane (97 mg, $0.47 \mathrm{mmol})$ in THF (5 mL) and $\mathrm{MeOH}$ $(5 \mathrm{~mL})$ was added $\mathrm{K}_{2} \mathrm{CO}_{3}(284 \mathrm{mg}, 2.05 \mathrm{mmol})$ and the mixture was stirred at $\mathrm{rt}$ for $1 \mathrm{~h}$. The mixture was poured through a plug of silica $\left(40-63 \mu \mathrm{m}, \mathrm{CH}_{2} \mathrm{Cl}_{2}\right)$, almost concentrated in vacuo and then THF $(50 \mathrm{~mL})$ was added and the mixture containing 6 was concentrated to approx. $10 \mathrm{~mL}$. Then 13 (110 mg, $0.437 \mathrm{mmol})$ and $\mathrm{Et}_{3} \mathrm{~N}(10 \mathrm{~mL})$ were added and the mixture was flushed with argon. $\mathrm{Pd}\left(\mathrm{PPh}_{3}\right)_{2} \mathrm{Cl}_{2}$ (35 mg, $50 \mu \mathrm{mol})$ and CuI (10 mg, $53 \mu \mathrm{mol})$ were added and the mixture was stirred for $22 \mathrm{~h}$ at rt. The reaction mixture was poured through a plug of silica $\left(40-63 \mu \mathrm{m}, \mathrm{CH}_{2} \mathrm{Cl}_{2}\right)$ and concentrated in vacuo. The crude material was subjected to flash column chromatography $\left(50 \% \mathrm{CH}_{2} \mathrm{Cl}_{2} /\right.$ heptane to $70 \% \mathrm{CH}_{2} \mathrm{Cl}_{2}$ /heptane) affording 15 as an off-white solid (80 mg, 53\%). $R_{f}\left(70 \% \mathrm{CH}_{2} \mathrm{Cl}_{2} /\right.$ heptane $)=$ 0.47. ${ }^{1} \mathrm{H}$ NMR $\left(500 \mathrm{MHz}, \mathrm{CDCl}_{3}\right): \delta=7.79-7.72(\mathrm{~m}, 4 \mathrm{H}), 7.48-7.42(\mathrm{~m}, 4 \mathrm{H}), 6.87(\mathrm{~d}, J=8.9 \mathrm{~Hz}, 2 \mathrm{H})$, $4.27(\mathrm{~m}, 1 \mathrm{H}), 4.23(\mathrm{~m}, 1 \mathrm{H}), 3.83(\mathrm{~s}, 3 \mathrm{H}), 2.66(\mathrm{dt}, J=8.4,1.6 \mathrm{~Hz}, 1 \mathrm{H}), 2.43(\mathrm{dt}, J=8.4,1.5 \mathrm{~Hz}, 1 \mathrm{H}) \mathrm{ppm}$. ${ }^{13} \mathrm{C}$ NMR $\left(126 \mathrm{MHz}, \mathrm{CDCl}_{3}\right): \delta=160.94,151.82,143.61,142.98,133.90,132.51,132.40,128.11,128.02$, $126.26,126.20,125.74,121.65,121.11,116.06,114.32,113.91,108.26,82.00,64.76,56.04,55.49,52.79$ ppm. HR-MS (ESI ${ }^{+}$FT-ICR): $m / z=348.13845\left[\mathrm{M}+\mathrm{H}^{+}\right]$, calcd. for $\left[\mathrm{C}_{25} \mathrm{H}_{18} \mathrm{NO}^{+}\right]: m / z=348.13829$.

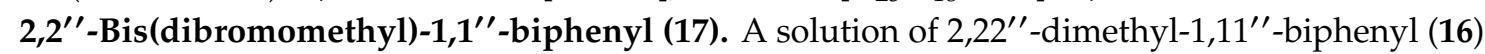
(13.5 mL, $73.3 \mathrm{mmol})$, NBS (58.10 g, $326.4 \mathrm{mmol})$ and Luperox ${ }^{\circledR}$ A75, Benzoyl peroxide $(1.35 \mathrm{~g}, 1.01 \mathrm{~g}$ benzoyl peroxide, $4.17 \mathrm{mmol})$ in benzene $(500 \mathrm{~mL})$ was heated to reflux point while irradiated with a $500 \mathrm{~W}$ halogen lamp for $18 \mathrm{~h}$. The mixture was allowed to cool to rt, poured through a plug of silica (43-60 $\mu \mathrm{m})$ and concentrated in vacuo. The crude mixture was recrystallized from $\mathrm{CH}_{2} \mathrm{Cl}_{2} / \mathrm{heptane}$ affording 17 as an off-white solid $(30.10 \mathrm{~g}, 83 \%)$. The reaction was also performed on $5.49 \mathrm{mmol}$ scale giving a yield of $76 \% .{ }^{1} \mathrm{H}$ NMR $\left(500 \mathrm{MHz}, \mathrm{CDCl}_{3}\right): \mathrm{d}=8.13(\mathrm{dd}, J=7.8,1.3 \mathrm{~Hz}, 2 \mathrm{H}), 7.58(\mathrm{td}, J=7.8$, $1.4 \mathrm{~Hz}, 2 \mathrm{H}), 7.41(\mathrm{td}, J=7.8,1.3 \mathrm{~Hz}, 2 \mathrm{H}), 7.12(\mathrm{dd}, J=7.8,1.4 \mathrm{~Hz}, 2 \mathrm{H}), 6.29(\mathrm{~s}, 2 \mathrm{H}) \mathrm{ppm} .{ }^{13} \mathrm{C} \mathrm{NMR}$ (126 MHz, CDCl3): $\delta=140.46,133.62,130.56,129.96,129.74,129.05,38.55$ ppm.

9,10-Dibromophenanthrene (18). To a solution of 17 (29.59 g, $59.44 \mathrm{mmol})$ in anhydrous DMF $(450 \mathrm{~mL})$ at $0{ }^{\circ} \mathrm{C}$ was added potassium tert-butoxide $(21.65 \mathrm{~g}, 192.9 \mathrm{mmol})$. The mixture was stirred at $0{ }^{\circ} \mathrm{C}$ for $1 \mathrm{~h}$, before the mixture was quenched slowly with $6 \mathrm{M} \mathrm{HCl}(500 \mathrm{~mL})$. The precipitate was filtered, washed with water $(1.5 \mathrm{~L})$ and $\mathrm{MeOH}(200 \mathrm{~mL})$ and dried in vacuo affording 18 as a yellow solid $(18.10 \mathrm{~g}, 91 \%)$. The reaction was also done on $3.02 \mathrm{mmol}$ scale giving a yield of $79 \% .{ }^{1} \mathrm{H}$ NMR $\left(500 \mathrm{MHz} \mathrm{CDCl}_{3}\right): \delta=8.63(\mathrm{dd}, J=8.2,1.4 \mathrm{~Hz}, 2 \mathrm{H}), 8.47(\mathrm{dd}, J=8.1,1.5 \mathrm{~Hz}, 2 \mathrm{H}), 7.70(\mathrm{ddd}, J=8.2$, 7.0, $1.5 \mathrm{~Hz}, 2 \mathrm{H}), 7.66(\mathrm{ddd}, J=8.1,7.0,1.4 \mathrm{~Hz}, 2 \mathrm{H}) .{ }^{13} \mathrm{C}$ NMR $\left(126 \mathrm{MHz}, \mathrm{CDCl}_{3}\right): \delta=131.27,130.36$,

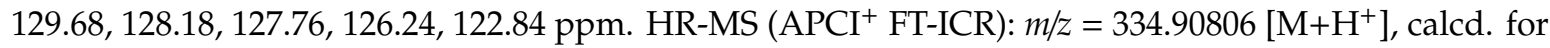
$\left[\mathrm{C}_{14} \mathrm{H}_{9}{ }^{79} \mathrm{Br}_{2}{ }^{+}\right]: m / z=334.90655$.

1,4-Dihydro-1,4-methanotriphenylene (19). To solution of 18 (17.84 g, $53.09 \mathrm{mmol}$ ) and cyclopentadiene $(4.8 \mathrm{~mL}, 57 \mathrm{mmol})$ in anhydrous toluene $(600 \mathrm{~mL})$ at $0{ }^{\circ} \mathrm{C}$ was added $n$-BuLi (23.4 mL, 2.5 M in hexane, $58.5 \mathrm{mmol})$. The mixture was allowed to reach rt slowly overnight, before it was poured into water $(1 \mathrm{~L})$ and extracted with $\mathrm{Et}_{2} \mathrm{O}(3 \times 500 \mathrm{~mL})$. The combined organic phases were dried over $\mathrm{Na}_{2} \mathrm{SO}_{4}$, filtered and concentrated in vacuo. The residue was passed through a plug of silica (43-60 $\mu \mathrm{m}, 50 \% \mathrm{CH}_{2} \mathrm{Cl}_{2}$ /heptane) and concentrated in vacuo. Flash column chromatography (heptane to $5 \% \mathrm{CH}_{2} \mathrm{Cl}_{2} /$ heptane) afforded 19 as a white solid $(5.80 \mathrm{~g}, 45 \%)$. ${ }^{1} \mathrm{H} \mathrm{NMR}\left(500 \mathrm{MHz}, \mathrm{CDCl}_{3}\right): \delta=8.73$ $(\mathrm{d}, J=8.1 \mathrm{~Hz}, 2 \mathrm{H}), 8.06(\mathrm{dd}, J=8.0,1.4 \mathrm{~Hz}, 2 \mathrm{H}), 7.64(\mathrm{ddd}, J=8.0,6.9,1.3 \mathrm{~Hz}, 2 \mathrm{H}), 7.59(\mathrm{ddd}, J=8.1$, $6.9,1.4 \mathrm{~Hz}, 2 \mathrm{H}), 7.03(\mathrm{~d}, J=1.7 \mathrm{~Hz}, 2 \mathrm{H}), 4.64(\mathrm{~m}, 2 \mathrm{H}), 2.56(\mathrm{dt}, J=6.6,1.7 \mathrm{~Hz}, 1 \mathrm{H}), 2.47(\mathrm{dt}, J=6.6,1.7$ $\mathrm{Hz}, 1 \mathrm{H})$ ppm. ${ }^{13} \mathrm{C}$ NMR $\left(126 \mathrm{MHz} \mathrm{CDCl}_{3}\right): \delta=147.89,143.78,129.00,128.73,126.51,125.26,123.55$, 123.54, 72.46, 49.22 ppm. HR-MS (APCI ${ }^{+}$FT-ICR): $m / z=243.11693\left[\mathrm{M}+\mathrm{H}^{+}\right]$, calcd. for $\left[\mathrm{C}_{14} \mathrm{H}_{19}{ }^{+}\right]: m / z=$ 243.11683.

2-Bromo-3-chloro-1,4-dihydro-1,4-methanotriphenylene (20). To a solution of $t$-BuOK (1.93 g, $17.2 \mathrm{mmol})$ in THF $(300 \mathrm{~mL})$ at $-78^{\circ} \mathrm{C}$ was added $19(5.13 \mathrm{~g}, 21.2 \mathrm{mmol})$. The cooling bath was removed until everything was in solution, before the mixture was cooled once again to $-78^{\circ} \mathrm{C}$. $n$-BuLi (6.85 mL, $2.5 \mathrm{M}$ in hexanes, $17.1 \mathrm{mmol}$ ) was added over the course of $45 \mathrm{~min}$ resulting in a dark red/brown color. The temperature was elevated to $-41^{\circ} \mathrm{C}$ and the mixture was stirred for $1 \mathrm{~h}$. The mixture was cooled to 
$-78{ }^{\circ} \mathrm{C}$ and $p$-toluenesulfonyl chloride $(3.26 \mathrm{~g}, 17.1 \mathrm{mmol})$ was added. The reaction mixture was stirred for $40 \mathrm{~min}$, before $n$-BuLi $(6.85 \mathrm{~mL}, 2.5 \mathrm{M}$ in hexanes, $17.1 \mathrm{mmol})$ was added over the course of $40 \mathrm{~min}$. The temperature was elevated to $-41^{\circ} \mathrm{C}$ and the mixture was stirred for $1 \mathrm{~h}$. The mixture was cooled to $-78^{\circ} \mathrm{C}$, before $p$-toluenesulfonyl bromide $(4.04 \mathrm{~g}, 17.2 \mathrm{mmol})$ was added and the mixture was stirred for $15 \mathrm{~min}$ at $-78^{\circ} \mathrm{C}$. The mixture was heated to ambient temperature using a room tempered water bath, before water $(150 \mathrm{~mL})$ was added. The remaining THF was removed in vacuo and the resulting mixture was extracted with $\mathrm{CH}_{2} \mathrm{Cl}_{2}(3 \times 300 \mathrm{~mL})$. The combined organic phases were washed with brine $(300 \mathrm{~mL})$, dried over $\mathrm{MgSO}_{4}$, filtered and concentrated in vacuo. Flash column chromatography (heptane to $5 \% \mathrm{CH}_{2} \mathrm{Cl}_{2}$ /heptane) furnished 19 and 20 (estimated yield of 32\%) as a 61:39 mixture (based on NMR integration) (4.03 g). The mixture of 19 and 20 was used in the next step without further purification.

3-Chloro-1,4-dihydro-1,4-methanotriphenylene-2-carbonitrile (21). To an argon-flushed solution of the mixture of 19 and 20 (3.93 g) in DMF $(50 \mathrm{~mL})$ was added CuCN $(406 \mathrm{mg}, 4.53 \mathrm{mmol})$ and the mixture was heated to $105{ }^{\circ} \mathrm{C}$ and stirred for $7 \mathrm{~h}$. The mixture was allowed to cool to rt before it was poured into saturated aqueous sodium carbonate $(300 \mathrm{~mL})$ and extracted with diethyl ether $(6 \times 100 \mathrm{~mL})$. The combined organic phases were washed with water $(4 \times 250 \mathrm{~mL})$ and brine $(2 \times 250 \mathrm{~mL})$, dried over $\mathrm{Na}_{2} \mathrm{SO}_{4}$, filtered and concentrated in vacuo. Flash column chromatography (30\% $\mathrm{CH}_{2} \mathrm{Cl}_{2} /$ heptane to $70 \% \mathrm{CH}_{2} \mathrm{Cl}_{2} /$ heptane, loaded in $1: 4 \mathrm{CH}_{2} \mathrm{Cl}_{2} / \mathrm{CS}_{2}$ ) afforded 21 as a white solid (402 mg, 25\%). ${ }^{1} \mathrm{H}$ NMR (500 MHz, $\left.\mathrm{CDCl}_{3}\right): \delta=8.79-8.72(\mathrm{~m}, 2 \mathrm{H}), 8.08-8.00(\mathrm{~m}, 2 \mathrm{H}), 7.73-7.64(\mathrm{~m}, 4 \mathrm{H})$, $4.89(\mathrm{~m}, 1 \mathrm{H}), 4.72(\mathrm{~m}, 1 \mathrm{H}), 3.00(\mathrm{dt}, J=7.5,1.8 \mathrm{~Hz}, 1 \mathrm{H}), 2.72(\mathrm{dt}, J=7.5,1.8 \mathrm{~Hz}, 1 \mathrm{H}) \mathrm{ppm} .{ }^{13} \mathrm{C} \mathrm{NMR}$ $\left(126 \mathrm{MHz} \mathrm{CDCl}_{3}\right): \delta=165.75,145.27,142.82,129.58,129.54,128.30,128.12,127.36,127.27,126.82$, $126.59,123.81,123.72,123.64,123.45,121.67,114.24,70.39,57.32,52.80$ ppm. HR-MS (ESI ${ }^{+}$FT-ICR): $^{-}$ $m / z=302.07324\left[\mathrm{M}+\mathrm{H}^{+}\right]$, calcd. for $\left[\mathrm{C}_{20} \mathrm{H}_{13} \mathrm{ClN}^{+}\right]: \mathrm{m} / z=302.07310$.

\section{3-((4-(Dimethylamino)phenyl)ethynyl)-1,4-dihydro-1,4-methanotriphenylene-2-carbonitrile}

(22). To a solution of $N, N$-dimethyl-4-((trimethylsilyl)ethynyl)aniline (92 mg, $0.42 \mathrm{mmol}$ ) in THF/MeOH $(20 \mathrm{~mL}, 1: 1, \mathrm{v} / \mathrm{v})$ was added $\mathrm{K}_{2} \mathrm{CO}_{3}(202 \mathrm{mg}, 1.46 \mathrm{mmol})$ and the mixture was stirred for $1 \mathrm{~h}$. The mixture was poured through a plug of silica $\left(43-60 \mu \mathrm{m}, \mathrm{CH}_{2} \mathrm{Cl}_{2}\right)$, almost concentrated in vacuo; then THF $(50 \mathrm{~mL})$ was added and the mixture containing 5 was concentrated to approx. $10 \mathrm{~mL}$. The 21 (106 mg, $351 \mu \mathrm{mol})$ and $\mathrm{Et}_{3} \mathrm{~N}(10 \mathrm{~mL})$ were added and the mixture was flushed with argon. $\mathrm{Pd}_{(}\left(\mathrm{PPh}_{3}\right)_{2} \mathrm{Cl}_{2}$ $(26 \mathrm{mg}, 37 \mu \mathrm{mol})$ and $\mathrm{CuI}(6 \mathrm{mg}, 0.03 \mathrm{mmol})$ were added before the mixture was stirred for $18 \mathrm{~h}$. The mixture was poured through a plug of silica $\left(43-60 \mu \mathrm{m}, \mathrm{CH}_{2} \mathrm{Cl}_{2}\right)$ and concentrated in vacuo. The residue was purified by flash column chromatography (50-70\% $\mathrm{CH}_{2} \mathrm{Cl}_{2}$ /heptanes) affording 22 as a yellow solid (99 mg, 69\%). ${ }^{1} \mathrm{H}$ NMR (500 MHz, $\left.\mathrm{CDCl}_{3}\right): \delta=8.76-8.71(\mathrm{~m}, 2 \mathrm{H}), 8.14-8.05(\mathrm{~m}, 2 \mathrm{H})$, $7.72-7.60(\mathrm{~m}, 4 \mathrm{H}), 7.35(\mathrm{~d}, J=9.0 \mathrm{~Hz}, 2 \mathrm{H}), 6.61(\mathrm{~d}, J=9.0 \mathrm{~Hz}, 2 \mathrm{H}), 4.88(\mathrm{~m}, 1 \mathrm{H}), 4.85(\mathrm{~m}, 1 \mathrm{H}), 3.00(\mathrm{~s}$, $6 \mathrm{H}), 2.86(\mathrm{dt}, J=7.5,1.6 \mathrm{~Hz}, 1 \mathrm{H}), 2.65(\mathrm{dt}, J=7.5,1.6 \mathrm{~Hz}, 1 \mathrm{H}) \mathrm{ppm} .{ }^{13} \mathrm{C} \mathrm{NMR}\left(126 \mathrm{MHz}, \mathrm{CDCl}_{3}\right): \delta$ $=154.80,151.08,145.16,143.85,133.61,129.44,128.62,128.30,127.16,127.05,126.40,126.22,125.11$, $123.73,123.72,123.70,123.62,116.85,112.19,108.34,82.41,69.91,56.27,52.64,40.20$ ppm. HR-MS (ESI ${ }^{+}$ FT-ICR): $m / z=411.18508\left[\mathrm{M}+\mathrm{H}^{+}\right]$, calcd. for $\left[\mathrm{C}_{30} \mathrm{H}_{23} \mathrm{~N}_{2}{ }^{+}\right]: m / z=411.18558$.

3-((4-Methoxyphenyl)ethynyl)-1,4-dihydro-1,4-methanotriphenylene-2-carbonitrile (23). To a solution of ((4-methoxyphenyl)ethynyl)trimethylsilane $(118 \mathrm{mg}, 557 \mu \mathrm{mol})$ in THF/MeOH $(20 \mathrm{~mL}, 1: 1$, $v / v)$ was added $\mathrm{K}_{2} \mathrm{CO}_{3}(213 \mathrm{mg}, 1.54 \mathrm{mmol})$ and the mixture was stirred for $1 \mathrm{~h}$. The mixture was poured through a plug of silica $\left(43-60 \mu \mathrm{m}, \mathrm{CH}_{2} \mathrm{Cl}_{2}\right)$, almost concentrated in vacuo and then THF $(50 \mathrm{~mL})$ was added and the mixture containing 6 was concentrated to approx. $10 \mathrm{~mL}$. Then 21 (153 mg, $507 \mu \mathrm{mol})$ and $\mathrm{Et}_{3} \mathrm{~N}(10 \mathrm{~mL})$ were added and the mixture was flushed with argon. $\mathrm{Pd}_{(}\left(\mathrm{PPh}_{3}\right)_{2} \mathrm{Cl}_{2}$ (37 mg, $52 \mu \mathrm{mol})$ and CuI $(89 \mu \mathrm{mol})$ were added before the mixture was stirred for $17 \mathrm{~h}$. The mixture was poured through a plug of silica $\left(43-60 \mu \mathrm{m}, \mathrm{CH}_{2} \mathrm{Cl}_{2}\right)$ and concentrated in vacuo. The residue was purified by flash column chromatography (50-60\% $\mathrm{CH}_{2} \mathrm{Cl}_{2}$ /heptanes) affording 23 as a slightly yellow solid (143 mg, 71\%). $R_{f}\left(60 \% \mathrm{CH}_{2} \mathrm{Cl}_{2} /\right.$ heptanes $)=0.25 .{ }^{1} \mathrm{H} \mathrm{NMR}\left(500 \mathrm{MHz}, \mathrm{CDCl}_{3}\right): \delta=8.77-8.71(\mathrm{~m}$, $2 \mathrm{H}), 8.14-8.05(\mathrm{~m}, 2 \mathrm{H}), 7.73-7.61(\mathrm{~m}, 4 \mathrm{H}), 7.42(\mathrm{~d}, J=8.9 \mathrm{~Hz}, 2 \mathrm{H}), 6.86(\mathrm{~d}, J=8.9 \mathrm{~Hz}, 2 \mathrm{H}), 4.90(\mathrm{~m}$, $1 \mathrm{H}), 4.87(\mathrm{~m}, 1 \mathrm{H}), 3.82(\mathrm{~s}, 3 \mathrm{H}), 2.88(\mathrm{dt}, J=7.5,1.6 \mathrm{~Hz}, 1 \mathrm{H}), 2.68(\mathrm{dt}, J=7.5,1.6 \mathrm{~Hz}, 1 \mathrm{H}) \mathrm{ppm} .{ }^{13} \mathrm{C}$ 
NMR (126 MHz, $\left.\mathrm{CDCl}_{3}\right): \delta=160.91,154.48,144.95,143.80,133.78,129.49,129.47,128.57,128.29,127.52$, 127.24, 127.11, 126.52, 126.34, 123.74, 123.70, 123.66, 123.65, 116.39, 114.32, 114.07, 109.83, 82.21, 70.22, 56.15, 55.51, 52.81 ppm. HR-MS (ESI ${ }^{+}$FT-ICR): $m / z=398.15389\left[\mathrm{M}+\mathrm{H}^{+}\right]$, calcd. for $\left[\mathrm{C}_{29} \mathrm{H}_{20} \mathrm{NO}^{+}\right]$: $m / z=398.15394$.

Supplementary Materials: NMR Spectra of all new compounds. Details on photosensitizer experiments.

Author Contributions: Conceptualization, M.M., K.M.-P. and M.B.N.; Investigation, M.M., L.F. and Z.W.; Project administration, K.M.-P. and M.B.N.; Supervision, K.M.-P. and M.B.N.; Writing-original draft, M.M. and M.B.N.; Writing-review and editing, L.F., Z.W. and K.M.-P. All authors have read and agreed to the published version of the manuscript.

Funding: This research was funded by University of Copenhagen and the Knut and Alice Wallenberg Foundation.

Conflicts of Interest: The authors declare no conflict of interest.

\section{References}

1. Yoshida, Z. New molecular energy storage systems. J. Photochem. 1985, 29, 27-40. [CrossRef]

2. Lennartson, A.; Roffrey, A.; Moth-Poulsen, K. Designing photoswitches for molecular solar thermal energy storage. Tetrahedron Lett. 2015, 56, 1457-1465. [CrossRef]

3. Sun, C.-L.; Wang, C.; Boulatov, R. Applications of Photoswitches in the Storage of Solar Energy. ChemPhotoChem 2019, 3, 268-283. [CrossRef]

4. Miki, S.; Asako, Y.; Yoshida, Z. Photochromic Solid Films Prepared by Doping with Donor-Acceptor Norbornadienes. Chem. Lett. 1987, 195-198. [CrossRef]

5. Gray, V.; Lennartson, A.; Ratanalert, P.; Börjesson, K.; Moth-Poulsen, K. Diaryl-substituted norbornadienes with red-shifted absorption for molecular solar thermal energy storage. Chem. Commun. 2014, 50, 5330-5332. [CrossRef] [PubMed]

6. Quant, M.; Lennartson, A.; Dreos, A.; Kuisma, M.; Erhart, P.; Börjesson, K.; Moth-Poulsen, K. Low Molecular Weight Norbornadiene Derivatives for Molecular Solar-Thermal Energy Storage. Chem. Eur. J. 2016, 22, 13265-13274. [CrossRef] [PubMed]

7. Mansø, M.; Petersen, A.U.; Wang, Z.; Erhart, P.; Nielsen, M.B.; Moth-Poulsen, K. Molecular Solar Thermal Energy Storage: High energy densities and long storage times by photoswitch oligomers. Nat. Commun. 2018, 9, 1945. [CrossRef] [PubMed]

8. Paquette, L.A.; Cottrell, D.M.; Snow, R.A.; Gifkins, K.B.; Clardy, J. Substituent Control of Regiospecific Pathways in Di- $\pi$-methane Photorearrangements Which Utilize Benzo-Vinyl Bonding Schemes. J. Am. Chem. Soc. 1975, 97, 3275-3276. [CrossRef]

9. Santiago, C.; Houk, K.N.; Snow, R.A.; Paquette, L.A. Bridging Regioselectivity in Triplet-Sensitized Di- $\pi$-methane Photorearrangements of Ortho-Substituted Benzonorbornadienes. A Case for the Importance of Benzene HOMO and LUMO Polarization. J. Am. Chem. Soc. 1976, 98, 7443-7445. [CrossRef]

10. Snow, R.A.; Cottrell, D.M.; Paquette, L.A. Demonstration and Analysis of Bridgning Regioselectivity Operative during Di- $\pi$-methane Photorearrangement of Ortho-Substituted Benzonorbornadienes and anti-7,8-Benzotricyclo[4.2.2.02,5]deca-3,7,9-trines. J. Am. Chem. Soc. 1977, 99, 3734-3744. [CrossRef]

11. Skov, A.B.; Broman, S.L.; Gertsen, A.S.; Elm, J.; Jevric, M.; Cacciarini, M.; Kadziola, A.; Mikkelsen, K.V.; Nielsen, M.B. Aromaticity-Controlled Energy Storage Capacity of the Dihydroazulene-Vinylheptafulvene Photochromic System. Chem. Eur. J. 2016, 22, 14567-14575. [CrossRef] [PubMed]

12. Skov, A.B.; Petersen, J.F.; Elm, J.; Frandsen, B.N.; Santella, M.; Kilde, M.D.; Kjaergaard, H.G.; Mikkelsen, K.V.; Nielsen, M.B. Towards Storage of Solar Energy in Photochromic Molecules: Benzannulation of the Dihydroazulene/Vinylheptafulvene Couple. ChemPhotoChem 2017, 1, 206-212. [CrossRef]

13. Skov, A.B.; Ree, N.; Gertsen, A.S.; Chabera, P.; Lissau, J.S.; Nucci, L.; Pullerits, T.; Mikkelsen, K.V.; Nielsen, M.B.; Sølling, T.I.; et al. Excited State Topology Modifications of the Dihydroazulene Photoswitch Through Aromaticity. ChemPhotoChem 2019, 3, 619-629.

14. Lennartson, A.; Quant, M.; Moth-Poulsen, K. A Convenient Route to 2-Bromo-3-Chloronorbornadiene and 2,3-dibromonorbornadiene. Synlett 2015, 26, 1501-1504. 
15. Wang, B.-Y.; Turner, D.A.; Zujovic, T.; Hadad, C.M.; Badjic, J.D. The Role of Chirality in Direction the Formation of Cup-Shaped Porphyrins and the Coordination Characteristics of such Hosts. Chem. Eur. J. 2011, 17, 8870-8881. [CrossRef] [PubMed]

16. Pal, M.; Parasuraman, K.; Subramanian, V.; Dakarapu, R.; Yeleswarapu, K.R. Palladium mediated stereospecific synthesis of 3-enynyl substituted thioflavones/flavones. Tetrahedron Lett. 2004, 45, 2305-2309. [CrossRef]

17. Paddon-Row, M.N.; Patney, H.K. An Efficient Synthetic Strategy for Naphthalene Annellation of Norbornenylogous Systems. Synthesis 1986, 328-330. [CrossRef]

18. Hammond, G.S.; Turro, N.J.; Fischer, A. Photosensitized Cycloaddition Reactions. J. Am. Chem. Soc. 1961, 83, 4674-4765. [CrossRef]

Sample Availability: Samples of selected compounds are available from the authors.

(C) 2020 by the authors. Licensee MDPI, Basel, Switzerland. This article is an open access article distributed under the terms and conditions of the Creative Commons Attribution (CC BY) license (http://creativecommons.org/licenses/by/4.0/). 